\title{
Effects of exposure to air on planting stress in red oak seedlings
}

\author{
S Girard ${ }^{1,2}$, A Clément $^{3}$, B Boulet-Gercourt ${ }^{2}$, JM Guehl $^{1 *}$ \\ ' Équipe bioclimatologie et écophysiologie forestières, Centre Inra de Nancy, \\ 54280 Champenoux; \\ 2 Institut pour le développement forestier, 23, avenue Bosquet, 75007 Paris; \\ ${ }^{3}$ Équipe sol et nutrition, Centre Inra de Nancy, 54280 Champenoux, France
}

(Received 22 August 1996; accepted 9 January 1997)

\begin{abstract}
Summary - One-year-old bare-root red oak (Quercus rubra L) seedlings were lifted in March and exposed to desiccating conditions (darkness, $8{ }^{\circ} \mathrm{C}$ and $60 \%$ relative humidity) for $0,2,5,8$ and 12 days before planting in mini-rhizotrons. Water content and concentrations in soluble carbohydrates and starch were measured in buds, stems and roots after treatment and before planting. These variables were related to root and shoot growth after planting. Fifty percent of the seedlings exposed for 12 days did not regenerate new roots and died. No mortality was observed for the shorter exposure durations. Seedlings exposed for 0,2 and 5 days displayed similar new root elongation values after planting which were three-fold higher than those observed in seedlings exposed for 8 or 12 days. Exposure also induced bud abortion and formation of epicormic shoots. These perturbations appeared to be related to the desiccation of the different plant components, whereas non-structural carbohydrate concentrations were not affected during the exposure phase.
\end{abstract}

\section{dessication / root growth / shoot development / soluble sugars / starch}

Résumé - Effets de l'exposition à l'air sur le stress de transplantation chez le chêne rouge d'Amérique. Des plants de chêne rouge (Quercus rubra L) âgés de 1 an, à racines nues, arrachés en mars, ont été stockés en conditions ambiantes (obscurité, $8^{\circ} \mathrm{C}, 60 \%$ d'humidité relative) pendant 0 , $2,5,8$ et $12 \mathrm{j}$, avant d'être plantés en minirhizotrons. La teneur en eau et les concentrations en sucres solubles et en amidon des différents organes ont été mesurées après stockage et reliées au développement aérien et à la croissance racinaire après plantation. Cinquante pour cent des plants stockés pendant $12 \mathrm{j}$ n'ont pas régénéré de nouvelles racines et n'ont pas survécu. Aucune mortalité n'a été enregistrée pour les autres traitements. Les plants exposés durant 0,2 et $5 \mathrm{j}$ ont présenté des valeurs identiques d'élongation de nouvelles racines après transplantation. Ces valeurs étaient trois fois plus importantes que celles observées chez les plants stockés durant 8 ou $12 \mathrm{j}$. Les plants ont présenté, après transplantation, une descente de cime d'autant plus importante que la durée du stockage était longue.

* Correspondence and reprints

Tel: (33) 0383394041 ; fax: (33) 03833940 69; e-mail: guehl@nancy.inra.fr 
Ces perturbations apparaissent liées à une dessication des différentes composantes des plants au cours de la phase d'exposition et non à une diminution de la disponibilité en sucres non structuraux liée à leur utilisation respiratoire.

\section{dessèchement / croissance racinaire / développement aérien / sucres solubles / amidon}

\section{INTRODUCTION}

Adverse effects of exposure of bare-root coniferous seedlings to desiccating conditions before planting have been reported by several authors (Hermann, 1967; Coutts, 1981; Genç, 1996; Girard et al, 1997). Damage due to exposure of seedlings has been associated with the desiccation of the different tissues (Coutts, 1981; Sucoff et al, 1985). However, respiration during the exposure phase may also lead to a depletion in reserve carbohydrates in the plant tissues (Girard et al, 1997), possibly affecting seedling performance after planting through altered carbon metabolism (Puttonen, 1986; Guehl et al, 1993).

In contrast, the sensitivity of seedlings of deciduous species to exposure is less documented even though it has been suggested that dormant bare-root seedlings of deciduous species can withstand prolonged exposure without any appreciable damage in terms of survival (Briggs, 1939; Jobling, 1960; Insley and Buckley, 1985).

Red oak (Quercus rubra $\mathrm{L}$ ) is a major reforestation species in western Europe displaying a high sensitivity to transplanting stress (Courraud, 1983). The aim of this study was to assess the water and carbohydrate status of young red oak seedlings subjected to different exposure durations, typical of reforestation practices such as seedling transport and delayed planting, and to relate these variables to mortality and new root and shoot growth after planting.

\section{MATERIALS AND METHODS}

\section{Plant material and experimental set-up}

One hundred and ten one-year-old $(1+0)$ bareroot red oak seedlings were randomly lifted from a nursery near Auxerre (northeastern France) on 31 March 1993. Their average height and root collar diameter were $20 \mathrm{~cm}$ and $3.5 \mathrm{~mm}$, respectively. After lifting, stems and roots were both exposed to ambient conditions, without protection, in darkness, at $8{ }^{\circ} \mathrm{C}$ and $60 \%$ relative humidity for $0,2,5,8$ and 12 days (the water content of the different components was also measured after 20 days of exposure). At the end of each exposure period, ten seedlings were taken at random and used to measure water content and to determine soluble carbohydrate and starch concentrations in the different plant components (roots and stem). Another set of ten plants was planted in minirhizotrons and transferred in a phytotron under controlled environmental conditions for 50 days. Root regeneration and bud development were followed periodically until day 50 after transplanting.

\section{Growth parameters}

Immediately after lifting and after the different exposure durations, plants were planted in minirhizotrons (containers of $3 \times 30 \times 70 \mathrm{~cm}$ with a transparent side allowing root observations) filled with sphagnum peat and irrigated every second day. Environmental conditions in the phytotron were: air temperature, $22 \pm 0.2{ }^{\circ} \mathrm{C}$ (day) and 10 $\pm 0.2^{\circ} \mathrm{C}$ (night); relative air humidity, $60 \%$ (day) and $90 \%$ (night); photosynthetic photon flux density, $275 \pm 15 \mu \mathrm{mol} \mathrm{m}^{-2} \mathrm{~s}^{-1}$ provided by fluorescence tubes; ambient $\mathrm{CO}_{2}$ concentration, 440 $\pm 30 \mu \mathrm{mol} \mathrm{mol}{ }^{-1}$.

The length of elongating new roots was measured weekly after transplanting and bud development was assessed according to a six level scale: i) dormant bud (0); ii) swelled bud (20); iii) appearance of new leaves under scales (40); iv) leaves emerge from scales (60); v) unfolding of leaves (80); vi) leaves expanded and starting stem elongation (100). When no root growth and no bud development occurred after 50 days in phytotron, seedlings were considered as having died. 


\section{Plant water content}

Terminal buds (one apical + two subapical buds), the entire stem and the entire root system were separated, weighed and oven dried at $60{ }^{\circ} \mathrm{C}$ for 48 $\mathrm{h}$ (buds) or lyophilized for $48 \mathrm{~h}$ (stem and roots) before dry mass determination. Water content ( $\mathrm{g} \mathrm{H}_{2} \mathrm{O}$ per $\mathrm{g}$ dry mass) of the plant components was calculated from the fresh and dry masses.

\section{Carbohydrate concentrations}

Analyses were performed on each entire root system, after lyophilization and finely grinding. Soluble carbohydrates were extracted from $0.4 \mathrm{~g}$ of dry matter in $12 \mathrm{~mL}$ ethanol $(80 \%)$ at $60{ }^{\circ} \mathrm{C}$. The supernatant was separated from the residue by centrifugation for $15 \mathrm{mn}$. A second extraction was carried out with $8 \mathrm{~mL}$ ethanol. The two supernatants were mixed, purified on cation and anion exchange columns and evaporated to dryness under vacuum at $60^{\circ} \mathrm{C}$. The residue was redissolved before high performance liquid chromatography determination of the carbohydrates. The different sugars were quantified with standards. The most abundant soluble carbohydrates were glucose, fructose and sucrose. Melezitose was also detected, but in lower concentrations $\left(<5 \mathrm{mg} \mathrm{g}^{-1}\right.$ of dry matter), and was integrated in the soluble carbohydrate fraction. Starch extraction was carried out on $0.05 \mathrm{~g}$ of the pellet from soluble sugar extraction and measurement was performed using an enzymatic method (Boehringer-Mannheim). A more detailed description of these procedures is available in a previous paper (Girard et al, 1997). All carbohydrate data were expressed on a tissue dry weight basis. The concentrations of stem carbo- hydrates were determined from a mix of the ten stems per treatment. These measurements were made only for seedlings exposed for 0 and 12 days.

One-way factorial analysis of variance was used to determine the effects of exposure duration (experimental treatments) on water content and carbohydrate concentrations. Significance levels quoted are at $P<0.05$.

\section{RESULTS AND DISCUSSION}

\section{The effects of exposure on growth after planting}

Fifty percent of the seedlings submitted to the 12 day exposure died after transplanting (table I), whereas no mortality was observed for shorter exposure durations. From 5 days of exposure, abortion of terminal buds and desiccation (visual observations) of the upper part of the stem were observed 50 days after transplanting (table I). The distance between the stem apex and the location where the upper epicormic shoot was initiated increased with increasing exposure duration (table I), corresponding to a progressive abortion of buds along the stem. All surviving seedlings exposed for 12 days developed new shoots from an adventitious bud located below the root collar. Abortion of terminal buds and epicormic shoot formation were previously observed in young red oak seedlings sub-

Table I. Mortality, number of seedlings with terminal bud abortion and length of stem desiccation (distance from apex to the first developing epicormic shoot, mean values \pm 1 standard error of the mean) in the different exposure treatments 50 days after planting.

\begin{tabular}{cccc}
\hline $\begin{array}{c}\text { Exposure } \\
\text { duration }(\text { day })\end{array}$ & $\begin{array}{c}\text { Mortality } \\
(\mathrm{n}=10)\end{array}$ & $\begin{array}{c}\text { Abortion of terminal } \\
\text { buds }(\mathrm{n}=10)\end{array}$ & $\begin{array}{c}\text { Length of desiccated } \\
\text { stem }(\mathrm{cm})\end{array}$ \\
\hline 0 & 0 & 0 & 0 \\
2 & 1 & 0 & 0 \\
5 & 0 & 2 & $0.5 \pm 0.6$ \\
8 & 0 & 6 & $14.4 \pm 2.9$ \\
12 & 5 & 5 & $16.3 \pm 1.1$ \\
\hline
\end{tabular}


mitted to atmospheric or soil drought (Larson and Whitmore, 1970; Larson, 1980) or in lifted seedlings stored in drying conditions (Englert et al, 1993).
Exposure also affected bud and new shoot development (fig 1). In the seedlings exposed for 0,2 and 5 days, bud development occurred immediatly after transplant-
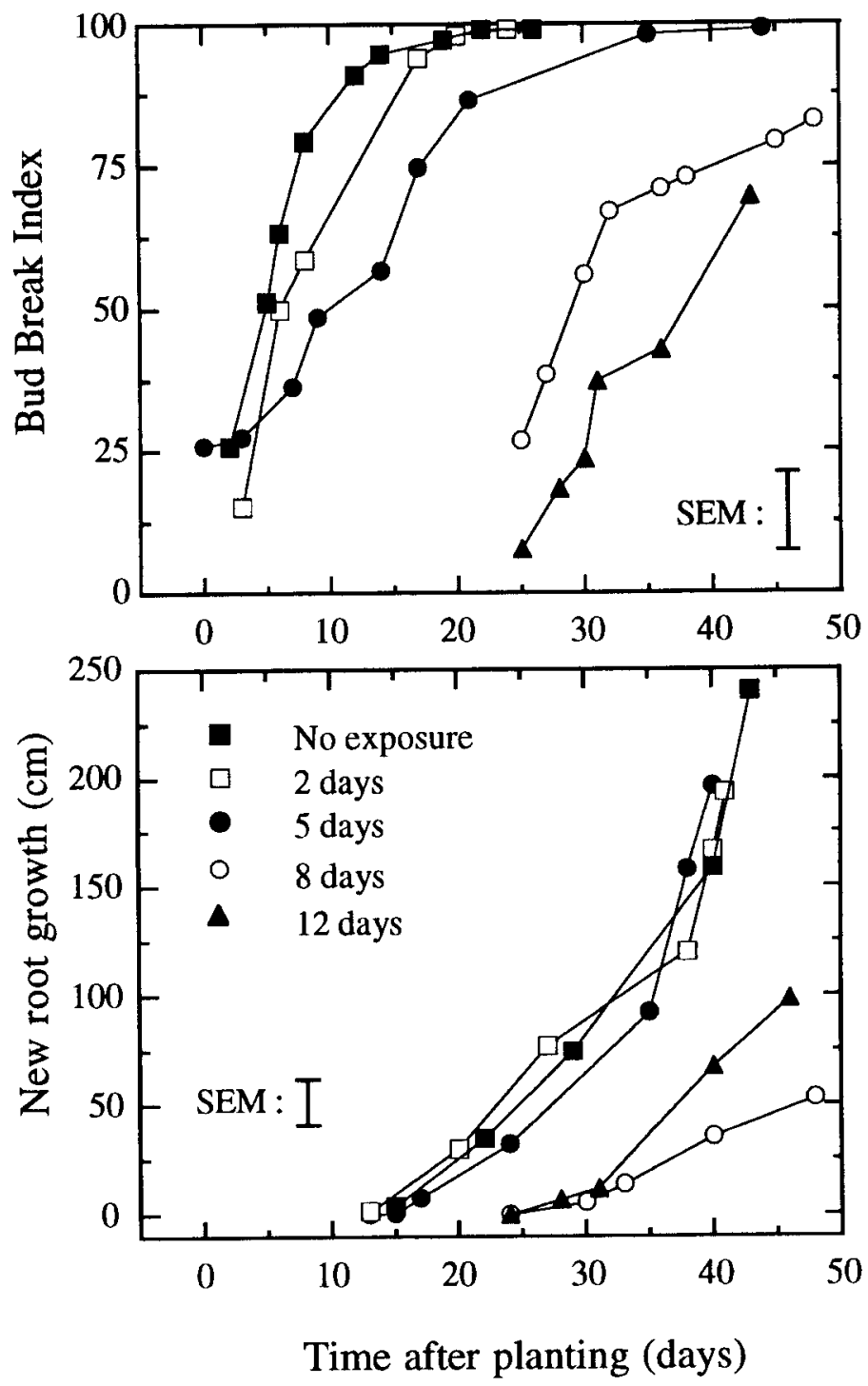

Fig 1. (Top) Time-course of bud break index and (bottom) cumulative new root elongation in surviving red oak seedlings after different exposure treatments. Vertical bar denotes the average values of standard crror of the mean (SEM). 
ing (fig 1), whereas it was delayed by about 25 days in the other treatments. Delayed bud break was also observed in Corsican pine exposed in the same conditions as here (Girard et al, 1997).

The first new roots appeared about 10 days after planting for the seedlings exposed for less than 8 days (fig 1). A longer exposure duration delayed new root appearance by about 10 days, showing that the capacity of red oak seedlings to elongate new roots can stay latent for weeks, as noted by Johnson et al (1984). At the end of this experiment (day 40), no significant differences in new root elongation were measured in seedlings exposed for 0,2 and 5 days, whereas new root growth was substantially lower for 8 and 12 days of exposure (fig 1).

\section{Desiccation of the different plant components}

Exposure caused a progressive desiccation of terminal buds, stems and root systems (fig 2). Desiccation was most rapid and marked in buds. The coarse root (mainly taproot) system of the seedlings desiccated with the same speed as the shoot, which contrasts with results reported for other species displaying a higher proportion of fine roots (Coutts, 1981; Sucoff et al, 1985).

\section{Carbohydrate concentrations}

Starch was clearly the predominant form of carbohydrate reserves in roots, but was pre-

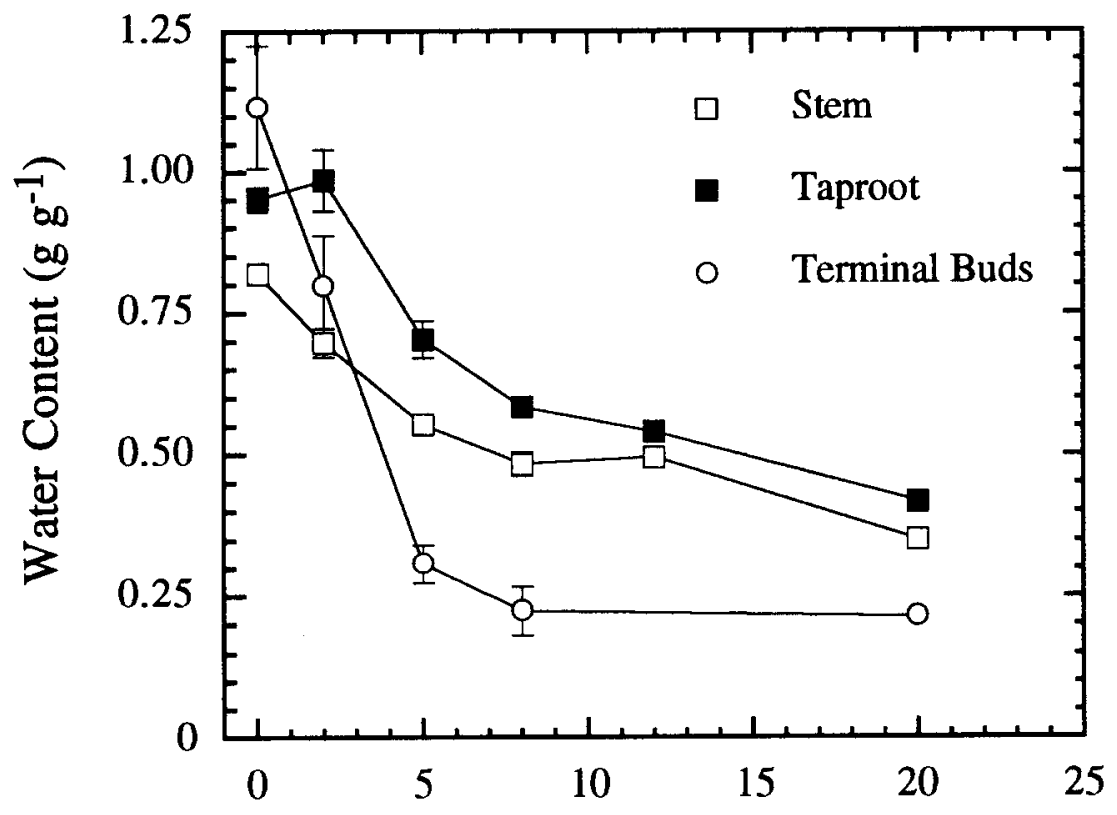

Number of days of exposure

Fig 2. Time-course of root, stem and bud water content during exposure of red oak seedlings. Data points represent average treatment values \pm 0.5 standard error of the mean (SEM) $(n=10)$. 
sent at very low concentration in stems (table II). Total non-structural carbohydrate (TNC) concentration was about seven times higher in roots than in stems. Exposure induced a slight decrease in root starch and TNC concentrations in the seedlings exposed for 2 days, as well as an increase in sucrose and soluble carbohydrate concentrations with increasing exposure durations (table II). Even though the increasing soluble carbohydrate concentration may point to the occurrence of osmoregulation in the roots, we do not have information enabling a straightforward metabolic interpretation of these results. Neither root nor stem TNC concentrations were significantly decreased at the end of the 12-day exposure period as compared with the non-exposed seedlings, suggesting a very low consumption of carbon reserves through respiration. This result is in contrast with the significant decrease in $\mathrm{TNC}$ concentrations found in Corsican pine seedlings exposed in the same conditions (Girard et al, 1996). The very low respiration rates suggested by our results might be explained by the low proportion of metabolically active tissues (absence of foliage and fine roots, predominance of reserve tissues of the taproot) in the exposed red oaks as compared with the coniferous species.

\section{CONCIUSION}

Exposure to ambient conditions had detrimental effects on bare-root red oak seedlings in terms of survival and growth after planting. The effects of exposure appeared to be related to the desiccation of the different plant components rather than to decreased carbon availability and consumption of carbohydrate reserves during the exposure phase. It would be worthwhile now to assess the effects of desiccation on the cellular integrity in the different tissues (McKay, 1992). The effects of exposure observed here were less pronounced than those obtained with Corsican pine seedlings exposed in identical conditions (Girard et al, 1996). Thus, our results tend to support the hypothesis of a lower sensitivity to exposure in deciduous than in evergreen coniferous seedlings, due to the absence of leaf transpiration during exposure in the former group (Insley and Buckley, 1985). Further work is needed to generalize this hypothesis.

Table II. Carbohydrate concentrations at the end of the different exposure treatments before planting.

\begin{tabular}{|c|c|c|c|c|c|c|c|}
\hline & $\begin{array}{c}\text { Exposure } \\
\text { duration (day) }\end{array}$ & $\begin{array}{l}\text { Glucose } \\
\left(m g g^{-1}\right)\end{array}$ & $\begin{array}{l}\text { Fructose } \\
\left(m g g^{\prime}\right)\end{array}$ & $\begin{array}{l}\text { Sucrose } \\
\left(n g g^{-l}\right)\end{array}$ & $\begin{array}{c}\text { Soluble carb. } \\
\left(m g g^{-l}\right)\end{array}$ & $\begin{array}{c}\text { Starch } \\
\left(m g g^{\prime}\right)\end{array}$ & $\begin{array}{c}T N C \\
\left(m g g^{-1}\right)\end{array}$ \\
\hline \multirow[t]{5}{*}{ Roots } & 0 & $6.1^{c}$ & $15^{\text {it }}$ & $28^{\mathrm{bc}}$ & $52^{\circ}$ & $206^{: 1}$ & $258^{a}$ \\
\hline & 2 & $5.0^{\mathrm{d}}$ & 15 & $25^{\circ}$ & $48^{\circ}$ & $179^{b}$ & $227^{\circ}$ \\
\hline & 5 & $7.2^{a b}$ & $15^{a}$ & $32^{b}$ & $59^{\mathrm{b}}$ & $183^{h}$ & $242: b$ \\
\hline & 8 & $6.5^{b c}$ & $15^{a}$ & $36^{b}$ & $61^{a b}$ & $182^{\mathrm{b}}$ & $243^{a b}$ \\
\hline & 12 & $7.4^{: 1}$ & $15^{a}$ & $43^{\mathrm{a}}$ & $69^{a}$ & $176^{b}$ & $245^{a b}$ \\
\hline \multirow[t]{2}{*}{ Stem } & 0 & 7.5 & 13 & 12 & 34 & 1 & 35 \\
\hline & 12 & 4.1 & 9 & 21 & 36 & 1 & 37 \\
\hline
\end{tabular}

For roots, data represent average treatment values $(n=10)$. For stems a single measurement was made using the pooled plant material from ten seedlings. TNC: total non-structural carbohydrates. abc For a given variable, mean values not sharing common letters are significantly different $(P \leq 0.05$, ANOVA and Fisher's PLSD separation test). 
From a practical point of view, it may be suggested from this study that cultural practices like packing seedlings in polyethylene bags (Webb and von Althen, 1980), rewatering after the exposure phase (Genç, 1996) or treating with antidesiccants (Englerts et al, 1993) can reduce water losses and minimize adverse effects of deferred planting.

\section{ACKNOWLEDGMENTS}

This work was supported by a grant from the Direction de l'Espace rural et des Forêts. The authors wish to thank M Bitsch, B Clere and F Willm for their technical assistance and G Aussenac for helpful discussions.

\section{REFERENCES}

Briggs AH (1939) Report of planting experiment to determine the effect of rool exposure on deciduous planting stock. J For 37, 939-943

Courraud (1983) Causes de la mauvaise reprise du chêne rouge d'Amérique. Forêt-Entreprise' 14, 2223

Coutts MP (1981) Effects of root or shoot exposure before planting on the water relations, growth, and survival of Sitka spruce. Can J For Res 11, 703. 709

Englert JM, Fuchigami LH, Chen THH (1993) Effects of storage temperatures and duration on the performance of bare-root deciduous hardwood trees. $I$ Arboriculture 19, 106-112

Genç M (1996) Effects of watering after lifting and exposure before planting on plant quality and per- formance in Oriental spruce. Ann Sci For 53, 139 143

Girard S, Guehl JM, Cochard H, Clement A, BouletGercourt B (1997) Eflects of exposure on planting stress in Corsican pine. Tree Physiol (in press)

Guehl JM, Clement A, Kaushal P, Aussenac G (1993) Planting stress, water status and non-structural carbohydrate concentrations in Corsican pinc seedlings. Tree Plusiol 12, 173-183

Hermann RK (1967) Seasonal variation in sensitivity of Douglas-fir seedlings to exposure of roots. Forest Sci 13, 140-149

Insley H, Buckley GP (1985) The influence of desiccation and root pruning on the survival and growth of broadleaved seedlings. J Hort Sci 60, 377-387

Jobling $\mathbf{J}$ (1960) Experiments on the handling of poplar planting stock. Rep Res For Conm London $1958 / 59,161-167$

Johnson PS, Novinger SL, Mares WG (1984) Root, shoot. and leaf area growth potentials of northern red oak planting stock. For Sci 30, 1017-1026

Larson MM (1980) Effects of atmospheric humidity and zonal soil water stress on initial growth of planted northern red oak seedlings. Can I For Res $10,549-554$

Larson MM, Whitmore FW (1970) Moisture stress allects root regeneration and early growth of red oak seedlings. For Sci 16, 495-498

McKay HM (1992) Electrolyte lcakage from fine roots of conifer seedlings: a rapid index of plant vitality following cold storage. Can J for Res 22, 1371 1377

Puttonen P (1986) Carbohydrate reserves in Pinus srhesfris seedling needles as an attribute of seedling vigor. Scand I For Res 1, 181-193

Sucoff E. Buschena C, Tamte P (1985) Desiccation and water potentials in the roots, leaves and shoots of bare-root red pinc and white spruce. Can I For 15.989.992 